\title{
Genetic and epigenetic silencing of the beclin 1 gene in sporadic breast tumors
}

Zidong $\mathrm{Li}^{1,2,3 \dagger}$, Bo Chen ${ }^{4 \dagger}$, Yiqing $\mathrm{Wu}^{1,2,3}$, Feng Jin ${ }^{4}$, Yongjing Xia ${ }^{1,2,3^{*}}$, Xiangjun Liu ${ }^{1,2,3}$

\begin{abstract}
Background: Beclin 1, an important autophagy-related protein in human cells, is involved in cell death and cell survival. Beclin 1 mapped to human chromosome 17q21. It is widely expressed in normal mammary epithelial cells. Although down-regulated expression with mono-allelic deletions of beclin 1 gene was frequently observed in breast tumors, whether there was other regulatory mechanism of beclin 1 was to be investigated. We studied the expression of beclin 1 and explored the possible regulatory mechanisms on its expression in breast tumors.
\end{abstract}

Methods: 20 pairs of tumors and adjacent normal tissues from patients with sporadic breast invasive ductal cancer (IDCs) were collected. The mRNA expression of beclin 1 was detected by real-time quantitative RT-PCR. Loss of heterozygosity $(\mathrm{LOH})$ was determined by real-time quantitative $P C R$ and microsatellite methods. The protein expression of beclin 1, p53, BRCA1 and BRCA2 was assessed by immunohistochemistry. CpG islands in 5' genomic region of beclin 1 gene were identified using MethylPrimer Program. Sodium bisulfite sequencing was used in examining the methylation status of each $\mathrm{CpG}$ island.

Results: Decreased beclin 1 mRNA expression was detected in 70\% of the breast tumors, and the protein levels were co-related to the mRNA levels. Expression of beclin 1 mRNA was demonstrated to be much higher in the BRCA1 positive tumors than that in the BRCA1 negative ones. Loss of heterozygosity was detected in more than $45 \%$ of the breast tumors, and a dense cluster of CpG islands was found from the $5^{\prime}$ end to the intron 2 of the beclin 1 gene. Methylation analysis showed that the promoter and the intron 2 of beclin 1 were aberrantly methylated in the tumors with decreased expression.

Conclusions: These data indicated that $\mathrm{LOH}$ and aberrant DNA methylation might be the possible reasons of the decreased expression of beclin 1 in the breast tumors. The findings here shed some new light on the regulatory mechanisms of beclin 1 in breast cancer.

\section{Background}

Autophagy is a process of cellular protein degradation through the autophagosomic-lysosomal pathway, which plays an important role in cell differentiation and maintenance of cellular homeostasis. However, it is usually defective in tumor cells [1,2]. Beclin 1, the mammalian orthologue of the yeast Atg6/Vps30 gene, is the first identified tumor suppressor gene in human to mediate autophagy $[3,4]$. It was originally isolated by a yeasttwo-hybrid screen and its protein was identified as an interacting partner of $\mathrm{Bcl}-2$, an important anti-apoptosis protein [5]. Beclin 1 has a regulatory role in the process

\footnotetext{
* Correspondence: yjxia@mail.tsinghua.edu.cn

† Contributed equally

'Institute of Biomedical Informatics, School of Medicine, Tsinghua University, Beijing, PR China
}

of vesicle nucleation of autophagy [5,6]. Previous studies demonstrated that over-expression of beclin 1 induced apoptosis via activation of caspase-9 in gastric cancer cells [7], while partial silencing of beclin 1 aggravated apoptosis in hepatic cancer cells [8]. The different effects of beclin 1 on cell death and cell survival in different cells depend on the cellular context.

Beclin 1 was mapped to a tumor susceptibility locus approximately $150 \mathrm{~kb}$ centromeric to $B R C A 1$ on human chromosome 17q21 [9]. Allelic loss of chromosome $17 q 21$ is often found in human prostate, breast and ovarian cancer [10-13]. Beclin 1 encodes an evolutionarily conserved $60 \mathrm{kDa}$ coiled coil protein that is widely expressed in human normal adult tissues [9]. It has been reported that reduced levels of beclin 1 expression and mono-allelic deletion were observed in human

\section{Biomed Central}


breast cancer cell lines and tissues [9]. Whether there are other mechanisms for the loss of beclin 1 expression in breast cancer remains to be determined.

DNA methylation is the major epigenetic modification that involves alterations of chromatin structure. There are increasing evidences that aberrant methylation of $\mathrm{CpG}$ islands in $5^{\prime}$ regulatory region of tumor suppressor gene leads to transcriptional silencing in cancer [14-16]. The human beclin 1 gene contains a $1.5 \mathrm{~kb}$ CpG island from the promoter to part of the intron 2, suggesting that DNA methylation may be responsible for downregulation of beclin 1 expression in cancer. In addition, the promoter-associated CpG island of beclin 1 contains E2F target site and four putative consensus Sp1 binding sites [17]. In the present study, we detected the mRNA and protein expression levels of beclin 1 and explored the possible effects of DNA methylation and $\mathrm{LOH}$ on decreased gene expression in breast cancer tissues. The results here provided some new insights into the regulation of beclin 1 in breast cancer.

\section{Methods}

\section{Tissue samples}

20 pairs of tumors and adjacent normal tissues from newly diagnosed patients with sporadic breast invasive ductal cancer (IDCs) were collected from the First Affiliated Hospital of China Medical University after the approval of Institutional Review Board and patients' informed consents. All the patients were females without family hereditary breast cancer. Radio and chemo therapy was not applied to the patients before surgical operation. The patients were consecutive cases. The median age of these patients was 48.5 year-old (range, 40 - 74). The clinicopathologic parameters, including patient's age, tumor size, tumor grade, lymph node status, estrogen receptor (ER), progesterone receptor (PR) and human epidermal growth factor receptor-type 2 (HER2) immunoreactivity were obtained from clinical records. The tissues were obtained after surgical resection and subsequently microdissected with the assistance of pathologists. The corresponding adjacent normal tissues were derived from sites adjacent at least $1 \mathrm{~cm}$ away from the tumors. Tissues for immunohistochemistry use were fixed in $10 \%$ buffered formalin, embedded in paraffin, and sectioned with a microtome. Sections were stained with hematoxylin and eosin for histological examination by at least two pathologists. Tissue fragments were immediately frozen and stored in liquid nitrogen till used.

RNA extraction and quantitative reverse transcription PCR Total RNA from tissues was extracted using TRIZOL reagent (Invitrogen) according to the manufacture's protocol. The first strand cDNA was obtained from total
RNA $(0.5 \mu \mathrm{g})$ and oligo (dT) using the Reverse Transcription System (Promega). For real-time quantitative RT-PCR, gene specific primers and TaqMan fluorescent hybridization probes were used. $\beta$-actin was used to normalize the quantity of specific mRNA. The sequences of beclin 1 and $\beta$-actin primers are listed in Table 1. The PCR product was 85 bp for beclin1 and $295 \mathrm{bp}$ for $\beta$-actin. Their authenticity was confirmed by DNA sequencing. The amplification efficiency determined for both target and housekeeping genes was equal. Relative expression levels were calculated by the $2^{-\Delta \Delta \mathrm{Ct}}$ method [18]. Each assay was done in triplicate.

\section{Genomic DNA extraction and quantitative PCR}

Genomic DNA of tumors and matched adjacent normal tissues was extracted with the Dneasy Tissue Kit (Qiagen). A Taqman-based quantitative PCR method using PRISM 7300 Real-Time PCR Thermal Cycler (Applied Biosystem) was applied to detect the relative copy number of beclin 1. DNA content per haploid genome was normalized to that of $18 \mathrm{~S}$ rDNA and calculated by the $2^{-\Delta \Delta \mathrm{Ct}}$ method [18]. Table 1 showed the sequences of the specific primer pairs and the Taqman probes. PCR products were sequenced to confirm their authenticity. Each assay was done in triplicate. A dilution series was performed to quantify primer efficiency.

\section{Mutational and microsatellite analysis}

To search for mutations of the beclin 1 gene by polymerase chain reaction - single strand conformation polymorphism (PCR-SSCP) analysis, each of the 12 exons was amplified using its specific primers. The sequences of the primers and PCR conditions were as described by Aita et al [9]. Denatured PCR products were loaded onto non-denaturing $6 \%$ polyacrylamide gels, electrophoresed at $4^{\circ} \mathrm{C}$, stained with silver staining, and visualized.

To analyze LOH of the beclin 1 gene, a microsatellite marker on 17q21, D17S579, was selected through UniSTS database of National Center for Biotechnology Information (NCBI). Primer sequences are shown in Table 1 . We defined $\mathrm{LOH}$ as a completely absent or significantly decreased signal intensity of one allele.

\section{Sodium bisulfite modification and sequencing}

The methylation status of the Beclin 1 CpG island was determined by the bisulfite sequencing method [19]. $0.5 \sim 1 \mu \mathrm{g}$ genomic DNA was digested with BamHI that does not cut within the sequence of the $\mathrm{CpG}$ island. DNA was denatured by $0.3 \mathrm{M} \mathrm{NaOH}$ at $42^{\circ} \mathrm{C}$ for 30 min. Then $3 \mathrm{M}$ sodium bisulfite (Sigma) and $10 \mathrm{mmol} / \mathrm{L}$ hydroquinone were added, which was further incubated at $50^{\circ} \mathrm{C}$ for $16 \mathrm{~h}$. Modified DNA was purified using Wizard DNA purification resin (Promega), re-treated 
Table 1 Nucleotide sequences of primers used

\begin{tabular}{|c|c|c|}
\hline Name & Sequence $\left(5^{\prime} \diamond 3^{\prime}\right)$ & Purpose \\
\hline $\mathrm{Bl}-\mathrm{F}$ & TGCAACCTTCCACATCT & RT-PCR \\
\hline $\mathrm{BI}-\mathrm{R}$ & TTCCACGGGAACACTG & RT-PCR \\
\hline$\beta$-actin-F & TCACCCACACTGTGCCCATCTACGA & RT-PCR \\
\hline$\beta$-actin- $\mathrm{R}$ & CAGCGGAACCGCTCATTGCCAATGG & RT-PCR \\
\hline $\mathrm{Bl}-\mathrm{QF}$ & TCTGCCTTCCTCTGTAG & $\mathrm{Q}-\mathrm{PCR}$ \\
\hline $\mathrm{BI}-\mathrm{QR}$ & TTCCACGGGAACACTG & Q-PCR \\
\hline 18S-QF & ACATCCAAGGAAGGCAGCAG & Q-PCR \\
\hline 18S-QR & TTCGTCACTACCTCCCCGG & Q-PCR \\
\hline Bl-Taqman & FAM-CACAGTGGACAGTTTGGCACAATCA-TAMRA & Q-PCR \\
\hline$\beta$-actin-Taqman & FAM-CAGCCGTGGCCATCTCTTGCTCGAA-TAMRA & Q-PCR \\
\hline 18S-Taqman & FAM-CGCGCAAATTACCCACTCCCGA-TAMRA & Q-PCR \\
\hline Bl-bs1F & GTTITTAAAGTGTTGGAATTATAAG & Bisulfite first PCR \\
\hline Bl-bs1R & AACTCCTAATCCACAAACTCACAA & Bisulfite first PCR \\
\hline Bl-bs1F' & TTGTTGTTGTTTGAGATGGAGTT & Bisulfite nested PCR \\
\hline Bl-bs1R' & AAAAATATAAAAACCAAAACC & Bisulfite nested PCR \\
\hline Bl-bs2F & GGGTTTGTGAGTTTGTGGATTAG & Bisulfite first PCR \\
\hline Bl-bs2R & AAAAAAAACTCCAATAAAAACC & Bisulfite first PCR \\
\hline Bl-bs2 $\mathrm{F}^{\prime}$ & AGTTTGTGGATTAGGAGTTITTGT & Bisulfite nested PCR \\
\hline Bl-bs2R' & TAAAAATTCCCAAACTCCCTTCTA & Bisulfite nested PCR \\
\hline Bl-bs3F & ATTTAGAAGGGAGTTTGGGAATT & Bisulfite first PCR \\
\hline Bl-bs3R & TTAAACCCTTCCATCCCTAAAAC & Bisulfite first PCR \\
\hline Bl-bs3F' & TITGGGTTTAAATTGTTITGTT & Bisulfite semi-nested PCR \\
\hline Bl-bs3R' & TТAAACCСТTССАТСССТAAAAC & Bisulfite semi-nested PCR \\
\hline Bl-bs4F & ATATTGTGGATTITTGAGAGTTIT & Bisulfite first PCR \\
\hline Bl-bs4R & AAATCTTTCTITACTACTAAAAACTCTCT & Bisulfite first PCR \\
\hline Bl-bs4F' & TTGTAATTTAAGTATTITGGGAGAT & Bisulfite nested PCR \\
\hline Bl-bs4R & СТСТАТTACCCAAACTAAAATACAATAATA & Bisulfite nested PCR \\
\hline D17S579F & AGTCCTGTAGACAAAACCTG & Microsatellite analysis \\
\hline D17S579R & CAGTTTCATACCAAGTTCCT & Microsatellite analysis \\
\hline
\end{tabular}

Q-PCR, quantitative PCR.

with $0.3 \mathrm{M} \mathrm{NaOH}$ at $37^{\circ} \mathrm{C}$ for $15 \mathrm{~min}$, precipitated with ethanol, and resuspended in $50 \mu \mathrm{L}$ water. Semi-nested or nested PCR was used to amplify these regions. Primer sequences are detailed in Table 1 . Five clones of each PCR sample were picked up and sequenced.

\section{Immunohistochemistry}

Protein expression of beclin 1 was performed on breast tissues fixed by formalin and embedded by paraffin. Slides of $4 \mu \mathrm{m}$ sections were deparaffinized with xylene and antigen retrieval was accomplished by heat. The sections were then incubated in $3 \%$ hydrogen peroxide at room temperature for $5 \mathrm{~min}$ to block endogenous peroxidase activity. Slides were then incubated with rabbit anti-beclin 1 polyclonal antibody (Cell Signaling) at 1:300 dilutions at $4^{\circ} \mathrm{C}$ overnight. Then rinse the slides three times in PBS for $5 \mathrm{~m}$ each and incubate in biotinlabeled rabbit anti-rabbit secondary antibodies for $1 \mathrm{~h}$ at room temperature. After washing three times with PBS, the staining was performed using 3, 3'- diaminobenzidine. Sections were counterstained with hematoxylin. Staining was considered positive when cytoplasmic staining was observed in at least $30 \%$ of the neoplastic cells. And staining intensity was the strength of the signal and was evaluated on a scale of 0 to 2: 0 , negative; $1+$, weak staining; $2+$, moderate/strong staining. We also compared IHC data between tumors and corresponding adjacent normal tissues by percentage of positive cells and intensity of staining to estimate the changes of beclin 1 expression.

P53 protein expression was performed using anti-p53 monoclonal antibody (Ab-8, Lab Vision Corporation), which recognized both wild type and mutant forms of the $\mathrm{p} 53$ protein. BRCA1 and BRCA2 protein expression were assessed using an anti-BRCA1 monoclonal antibody (Ab-1, Oncogene Research Products) and an antiBRCA2 polyclonal antibody (Ab-2, Oncogene Research Products). Samples were considered positive when $20 \%$, $10 \%$, and $10 \%$ of the cells were stained with $\mathrm{p} 53$, BRCA1 and BRCA2, respectively. 


\section{Data analysis}

Data were expressed as mean \pm standard deviation. The ratio of beclin 1 mRNA expression in the tumor to that in the corresponding adjacent normal tissue in each case was transformed using a common logarithm. For statistical comparisons of these log-transformed data between two groups, a t-test was used. All statistical analyses were performed using SPSS software, version 10.0 (SPSS Japan Inc., Tokyo, Japan). For all of the statistical tests, a two-sided p-value of less than 0.05 was considered statistically significant.

\section{Results}

\section{Down-regulated beclin 1 mRNA expression in breast} cancer tissues

We detected relative mRNA expression of beclin 1 of 20 breast tumor tissues vs. corresponding normal tissues by quantitative RT-PCR. The mean \pm SD beclin $1 / \beta$-actin mRNA level was $1.56 \pm 1.01$ for tumor tissues and 2.24 \pm 1.39 for adjacent normal tissues (Table 2). As a whole, down-regulated expression of beclin 1 was found in 14 out of $20(70 \%)$ of the breast cancer tissues (Figure 1). Furthermore, 6 out of $20(30 \%)$ in the breast tumors showed a significant decrease (tumor: normal tissue ratio $<0.5)$ of beclin 1 mRNA expression. Meanwhile,

\section{Table 2 Beclin $1 / \beta$-actin mRNA expression in breast} tissues

\begin{tabular}{cc}
\hline $\mathbf{n}=\mathbf{2 0}$ & Beclin $\mathbf{1 / \beta}$-actin mRNA expression \\
\hline Adjacent normal tissues & $2.24 \pm 1.39$ \\
Tumors & $1.56 \pm 1.01$ \\
& $p=0.034$
\end{tabular}

Data are means $\pm S D$. The numbers show the mean values of beclin $1 / \beta$-actin mRNA expression and standard deviation in 20 breast tumors and adjacent normal tissues. Statistical analysis was done by paired $t-$ test. down-regulated beclin 1 mRNA expression was not observed in 6 out of 20 (30\%) of the breast tumors compared to the corresponding normal tissues.

As was shown in Table 3, we analyzed the correlation between beclin 1 mRNA expression and clinicopathological parameters, including age, the presence of lymphatic invasion, estrogen receptor (ER), progesterone receptor (PR) and human epidermal growth factor receptor-type 2 (HER2). No detectable significant difference was observed.

\section{Immunohistochemical analysis of beclin 1 protein expression in breast tumors}

Sections of breast tumors were applied to analyze the protein expression of beclin 1 . The staining was cytoplasmic. 13 out of $20(65 \%)$ of tumors showed reduced beclin 1 staining (Figure 2C, 2D) and normal epithelial cells showed strong cytoplasmic beclin 1 expression (Figure 2A). As illustrated in Table 4, there was significant positive correlation between beclin $1 \mathrm{mRNA}$ expression and immunoreactivity in breast tumors $(\mathrm{p}<0.001)$.

\section{The correlation between beclin 1 mRNA expression and} p53, BRCA1 and BRCA2 protein expression in breast tumors

P53 protein over-expression was detected in 2 (10\%) out of 20 breast tumors (Figure 3A, Table 5). There was no obvious excess nuclear p53 protein staining in the corresponding normal tissues, which indicates that the p53 level in the normal tissues is low (Figure 3B). BRCA1 and BRCA2 positive nuclear staining was observed in 6 (30\%) and 9 (45\%) out of 20 breast tumors, respectively (Figure 3B, 3D, Table 5). Beclin 1 mRNA levels were significantly higher in the BRCA1 positive tumors than those in the BRCA1 negative ones $(\mathrm{p}=0.014)$ (Table 6).

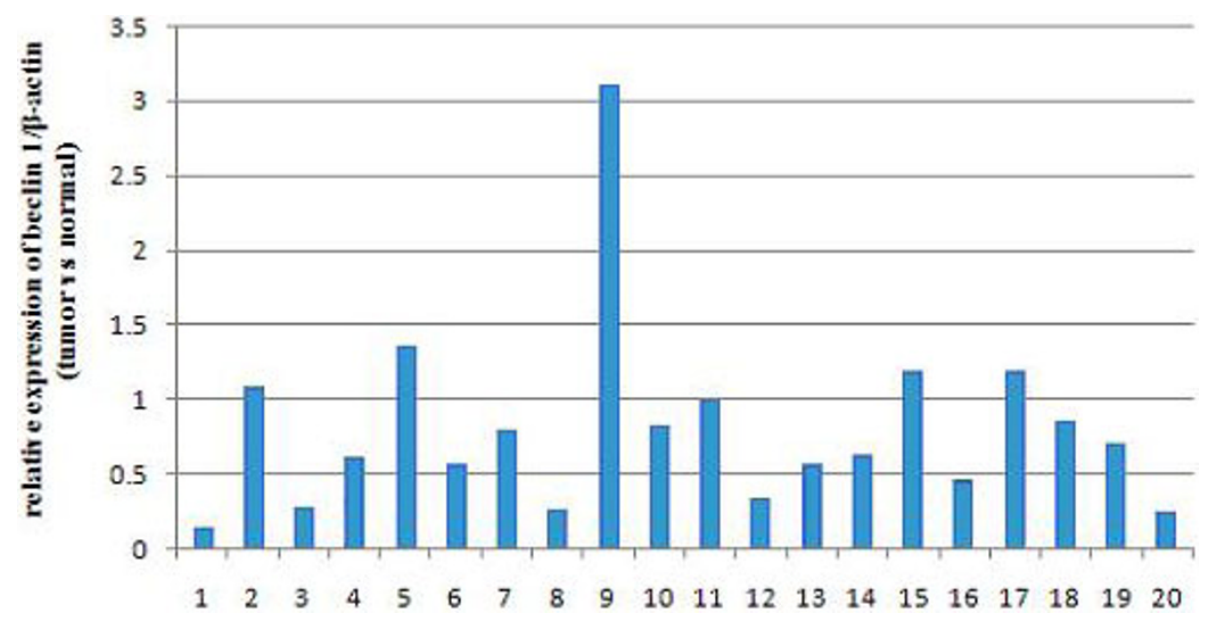

Figure 1 Beclin 1 mRNA relative expression of breast tumors vs adjacent normal tissues. Quantitative RT-PCR was carried out to detect the expression of beclin 1 with $\beta$-actin as an normalizer. 
Table 3 Correlation between beclin 1 mRNA expression in breast cancer and clinicopathologic parameters

\begin{tabular}{|c|c|c|c|c|}
\hline & Case number & Average of $\log \mathrm{T} / \mathrm{N}$ & Standard deviation of $\log T / N$ & P-value \\
\hline \multicolumn{5}{|l|}{ Age $(y)$} \\
\hline 50 & 11 & -0.13 & 0.06 & 0.160 \\
\hline$\geq 50$ & 9 & -0.30 & 0.07 & \\
\hline \multicolumn{5}{|c|}{ Lymphatic invasion } \\
\hline Positive & 8 & -0.23 & 0.06 & 0.356 \\
\hline Negative & 11 & -0.13 & 0.05 & \\
\hline \multicolumn{5}{|l|}{ ER } \\
\hline Positive & 7 & -0.31 & 0.08 & 0.199 \\
\hline Negative & 13 & -0.15 & 0.06 & \\
\hline \multicolumn{5}{|l|}{ PR } \\
\hline Positive & 10 & -0.20 & 0.06 & 0.905 \\
\hline Negative & 10 & -0.21 & 0.09 & \\
\hline \multicolumn{5}{|l|}{ HER2 } \\
\hline Positive & 19 & -0.21 & 0.07 & - \\
\hline Negative & 1 & -0.07 & - & \\
\hline
\end{tabular}

T, tumors; N, normal tissues; -, not applied.

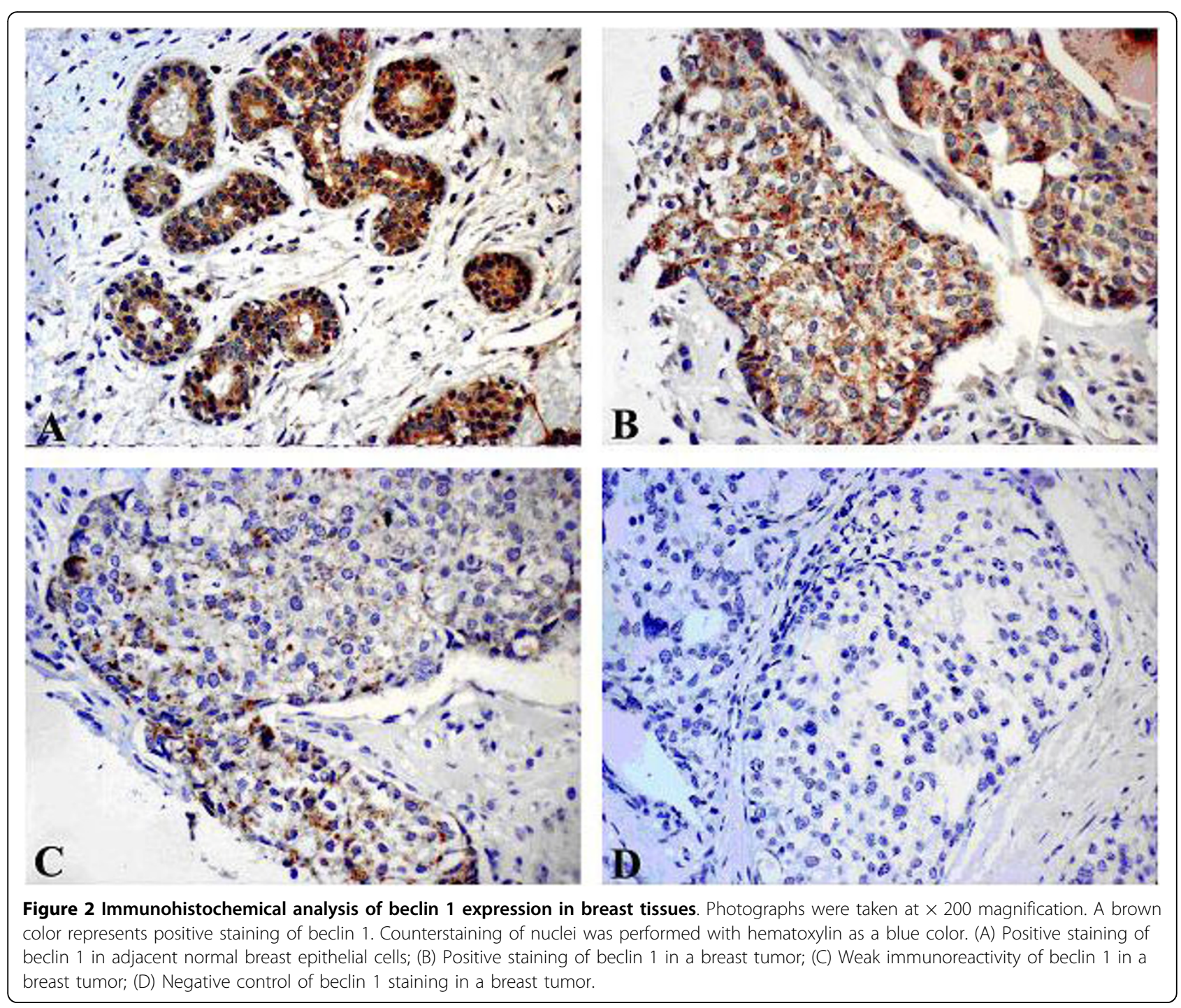


Table 4 Comparison between beclin 1 mRNA and protein expression in breast cancer

\begin{tabular}{ccc}
\hline Beclin $\mathbf{1}$ mRNA expression & Beclin $\mathbf{1}$ protein expression (IHC) \\
\hline (Quantitative RT-PCR) & Positive & Negative \\
\hline Positive (6) & 6 & 0 \\
Negative (14) & 1 & 13 \\
& $p<0.001$ & \\
\hline
\end{tabular}

Positive means that the expression level of beclin $1 \mathrm{mRNA} /$ protein in breast tumors increased compared with the corresponding adjacent normal tissues. And negative means that the expression level of beclin $1 \mathrm{mRNA}$ /protein in breast tumors decreased compared with the corresponding adjacent normal tissues. The association between beclin 1 mRNA and protein expression was analyzed using the $\chi^{2}$ test.

\section{LOH of beclin 1 was detected in some of the breast cancer tissues}

Using quantitative PCR method, beclin 1 gene copy number was detected in all breast tissues. As was shown in Table 5, LOH was found in 11 out of 20 (55\%) of breast tumors (tumor/normal < 1.0). Meanwhile, we applied a microsatellite marker, D17S579 [10], to validate the sensitivity of this methodology. $\mathrm{LOH}$ was verified in 9 out of 20 (45\%) of breast tumors (Figure 4, Table 5). Table 7 compared the correlation between both methods for $\mathrm{LOH}$ analysis. The results showed a significant relationship ( $\mathrm{p}<0.001$ ) between both methods, which exhibited accordance in $90 \%$ of cases.

\section{CpG island analysis in beclin 1 regulatory region}

Previous studies reported that beclin 1 maps to $17 \mathrm{q} 21$ that spans over $12 \mathrm{~kb}$ locus of human genome (Figure 5A) [9]. The $70 \mathrm{~kb}$ region of genome in which the beclin 1 gene residues, contains a moderate number of genes (Figure 5B). Telomerically flanking the beclin 1 gene is the PSME3 gene, a member of the PA28 family, which binds specifically to $20 \mathrm{~S}$ proteosomes and stimulates the hydrolysis of peptides [20], and the $A O C 2$ gene, a member of the copper-binding amine oxidase super family, which is an important regulator of cellular polyamine levels [21]. Centromerically flanking beclin 1 is the WNK4 gene, known to regulate thiazide-sensitive $\mathrm{Na}-\mathrm{Cl}$ co-transport [22], and the other two genes, CNTD1 and CCDC56 with unknown functions. Beclin gene is composed of 12 exons and exon 2 encodes the translational initial codon (ATG) (Figure 5C). 5' region of the beclin 1 gene was inspected by the MethPrimer program http://www.urogene.org/methprimer. The data showed this region of the genome to be a CG rich (Figure 5D). The CpG island encompassed from the promoter to the intron 2 (nt -528 to 977). Because aberrant cytosine methylation within $5^{\prime}$ end of tumor suppressor genes is commonly observed in cancer cells $[23,24]$, beclin 1 was likely a candidate gene for epigenetic silencing.
Certain CpG dinucleotides in the promoter and the intron 2 of the beclin 1 gene were methylated in breast tumors There are genetic and epigenetic alterations for the down-regulation of many genes. To identify mutations in the beclin 1 gene in breast cancer, mutational anlaysis was carried out by PCR-SSCP in genomic DNA of 20 breast tumors. No mutation was found in 12 exons of the beclin 1 gene in 20 breast tumors. As mentioned above, there was a large and dense $\mathrm{CpG}$ island ranging from the promoter to the intron 2 of the beclin 1 gene. Therefore, we first detected the methylation status of the CpG islands in the 6 breast tumors with significantly down-regulated beclin 1 expression and corresponding normal tissues by bisulfite sequencing. In the promoter from -528 to -65 (from transcription start site) and the intron 2 from 733 to 977, methylation was detected in 4 tumors $(\mathrm{T} 3,8,16,20)$ and weakly detected in the corresponding normal tissues. In the other two samples (T1, 12) with significantly down-regulated beclin 1 expression and $\mathrm{LOH}$, methylation was weakly detected in both tumors and corresponding normal tissues. Then we tested another 6 cases, whose beclin 1 mRNA expression was not down-regulated in breast tumors, and methylation was weakly or hardly detected in both tumors and normal tissues (Figure 6).

\section{Discussion}

It has been reported that tumor suppressor genes with high frequencies of $\mathrm{LOH}$ in human chromosomal region $17 q 21$ and epigenetic silencing, are important in hereditary and sporadic breast cancer tumorigenesis $[25,26]$. One of these genes is $B R C A 1$, whose decreased expression was often observed in breast cancer with epigenetic silencing and mono-allelic deletion of the BRCA1 gene [27-29]. In the present study, we showed that the mRNA and protein expression of beclin 1, another $17 q 21$ gene, was frequently down-regulated in breast tumors. This down-regulation in some tumors was due to allele loss in gene copy number and in some others was due to DNA methylation. There was no significant association between beclin 1 mRNA expression and clinocopathologic parameters.

P53, BRCA1 and BRCA2 are clearly involved in the development of both sporadic and hereditary breast cancers [30-34]. Mutations of these genes are the most common genetic variations and are widely distributed in breast cancer cells. Tumors with missense mutations displayed positive nuclear immunoreactivity of p53 for the effect of mutation on the prolongation of p53 halflife through increased protein stability [35]. Cancers with wild-type P53, including breast cancer [35], are generally negative for p53 immunoreactivity due to the rapid degradation of normal p53 protein. Meanwhile, loss or reduction of BRCA1 and BRCA2 expression has 

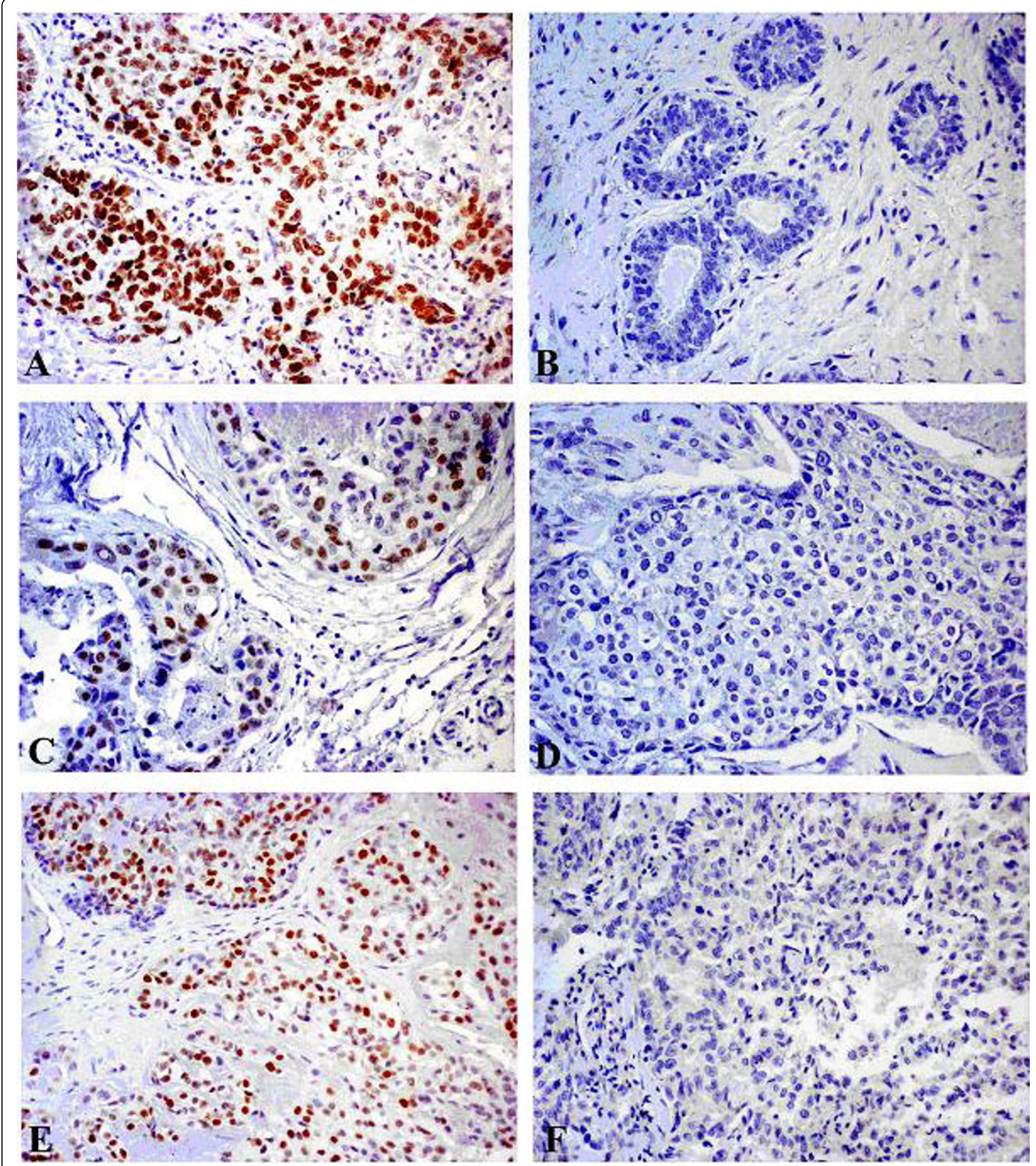

Figure 3 P53, BRCA1 and BRCA2 staining in breast tumors. Signals were photographed in breast tissues at $\times 200$. (A) Positive nuclear staining of p53 protein; (B) No obvious nuclear staining was observed over the whole normal breast tissue; (C) Positive nuclear staining of BRCA1 protein; (D) Negative control of BRCA1 staining in a breast tumor. (E) Positive nuclear staining of BRCA2 protein; (F) Negative control of BRCA2 staining in a breast tumor. 
Table 5 Beclin 1 mRNA and protein expression, p53, BRCA1 and BRCA2 protein expression and LOH analysis of beclin 1 in breast cancer tissues

\begin{tabular}{|c|c|c|c|c|c|c|c|}
\hline \multirow[t]{2}{*}{ Breast cancer cases } & \multirow[t]{2}{*}{ Beclin 1 mRNA expression } & \multicolumn{4}{|c|}{ Protein expression } & \multirow[t]{2}{*}{ LOH (Q-PCR) } & \multirow[t]{2}{*}{ LOH (microsatellite) } \\
\hline & & Beclin 1 & P53 & BRCA1 & BRCA2 & & \\
\hline 1 & - & - & - & - & - & + & + \\
\hline 2 & + & + & - & + & + & - & - \\
\hline 3 & - & - & - & - & - & + & + \\
\hline 4 & - & - & - & - & + & + & -+ \\
\hline 5 & + & + & - & + & - & - & - \\
\hline 6 & - & - & - & + & + & + & + \\
\hline 7 & - & - & - & + & + & + & + \\
\hline 8 & - & - & - & - & - & + & + \\
\hline 9 & + & + & - & - & - & - & - \\
\hline 10 & - & - & - & + & - & - & - \\
\hline 11 & + & + & + & - & + & + & + \\
\hline 12 & - & - & - & - & - & + & + \\
\hline 13 & - & - & - & - & + & + & + \\
\hline 14 & - & - & - & - & - & + & + \\
\hline 15 & + & + & - & - & - & - & - \\
\hline 16 & - & - & - & - & - & - & - \\
\hline 17 & + & + & + & + & + & + & - \\
\hline 18 & - & + & - & - & - & - & - \\
\hline 19 & - & - & - & - & + & - & - \\
\hline 20 & - & - & - & - & + & - & - \\
\hline
\end{tabular}

"+": positive; "-": negative.

Table 6 Relationship between beclin 1 mRNA expression and immunohistochemical characterization of p53, BRCA1 and BRCA2 in breast IDCs

\begin{tabular}{lcccc}
\hline & $\begin{array}{c}\text { Case } \\
\text { number }\end{array}$ & $\begin{array}{c}\text { Average of } \\
\text { log }\end{array}$ & $\begin{array}{c}\text { Standard } \\
\text { deviation }\end{array}$ & $\begin{array}{c}\text { P- } \\
\text { value }\end{array}$ \\
\hline p53 & $(\%)$ & T/N & of log T/N & \\
$\quad$ Positive & $2(10)$ & -0.24 & 0.24 & 0.798 \\
$\quad$ Negative & $18(90)$ & -0.20 & 0.06 & \\
BRCA1 & & & & \\
$\quad$ Positive & $6(30)$ & -0.01 & 0.02 & $0.014^{*}$ \\
$\quad$ Negative & $14(30)$ & -0.31 & 0.08 & \\
BRCA2 & & & & \\
$\quad$ Positive & $9(45)$ & -0.16 & 0.04 & 0.483 \\
$\quad$ Negative & $11(55)$ & -0.24 & 0.10 & \\
\hline
\end{tabular}

No obvious nuclear $\mathrm{p} 53$ protein staining was defined as negative and overexpression of $\mathrm{p} 53$ was defined as positive. Loss or reduction of BRCA1 and BRCA2 expression was defined as negative in tumors compared with the paired normal tissue, and vice versa.

been exhibited in sporadic breast cancers [36]. Immunohistochemistry of p53 and BRCA1/2 proteins in tumor cells may be useful as an additional method in exploring the relationship between the beclin 1 expression levels and the status of these important tumor suppressor genes in breast cancer. Therefore, we examined their expression levels by immunohistochemcial staining in 20 breast tumors. By IHC staining of p53 protein, we

\section{D17\$579}

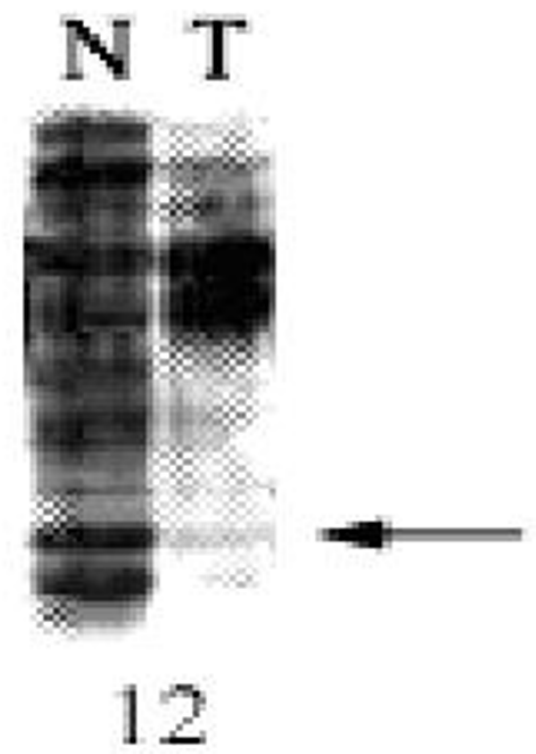

Figure 4 Representative photograph showing LOH in breast cancer. Above graph, microsatellite marker; under graph, patient's number; arrowheads, the allele losses; N, normal DNA; T, tumor DNA. 
Table 7 Comparison between microsatellite and quantitative - PCR method for LOH analysis of the beclin 1 gene in 20 paired tissues

\begin{tabular}{lcc}
\hline Q-PCR & \multicolumn{3}{c}{ D17S579 } \\
\hline & Negative & Positive \\
\hline Positive (13) & 2 & 11 \\
Negative (7) & 7 & 0 \\
& \multicolumn{2}{c}{$p<0.001$} \\
\hline
\end{tabular}

D17S579 was a microsatellite marker located in 17q21. Comparison was analyzed using the $\chi^{2}$ test.

found 2 cases (T11 and T17) exhibited more than 50\% positive nuclear staining cells of all tumor cells. IHC over-expression of p53 might reflect that genetic alterations also occurred in these tumors. We further analyzed the correlation between beclin 1 expression and p53 over-expression and no obvious association was obtained. It is known that the normal BRCA1 protein plays an important role in repairing breaks in DNA [37].
However, when BRCA1 exhibited loss of expression due to genetic or epigenetic alterations, abnormal repair function of BRCA1 may lead to DNA replication errors and cancerous growth [38,39]. Liang et al [3] reported that beclin 1 played a negative regulatory role in mammary cell growth and tumorigenesis using gene-transfer techniques. Our data showed that beclin 1 expression was significant higher in the BRCA1 positive tumors than in the negative ones, suggesting beclin 1 expression may be related to cell growth in breast cancer.

Beclin 1 is mapped to a region approximately $150 \mathrm{~kb}$ to $B R C A 1$ on chromosome $17 \mathrm{q} 21$, which is usually deleted in breast, ovarian and prostate cancer [8-11]. $\mathrm{LOH}$ at the beclin 1 locus was observed in 9 out 22 (41\%) of the breast cancer cell lines [9]. In the present study, all examined tumors exhibited a $\mathrm{LOH}$ rate of at least $45 \%$ at the beclin 1 locus and no mutation was found in the coding regions of beclin 1. These results confirmed that frequent allelic losses of beclin 1 were part of reasons for beclin 1 down-regulation and

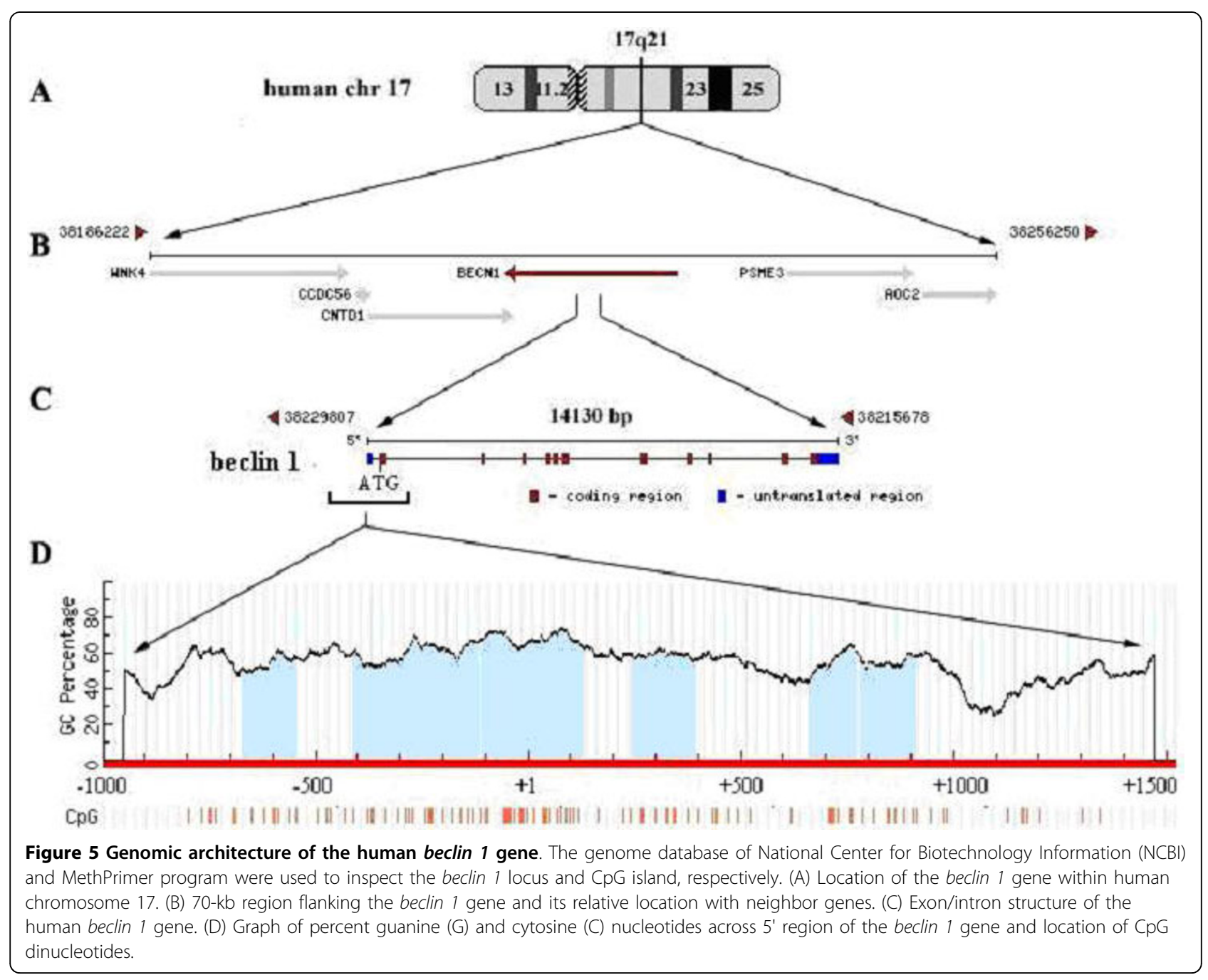




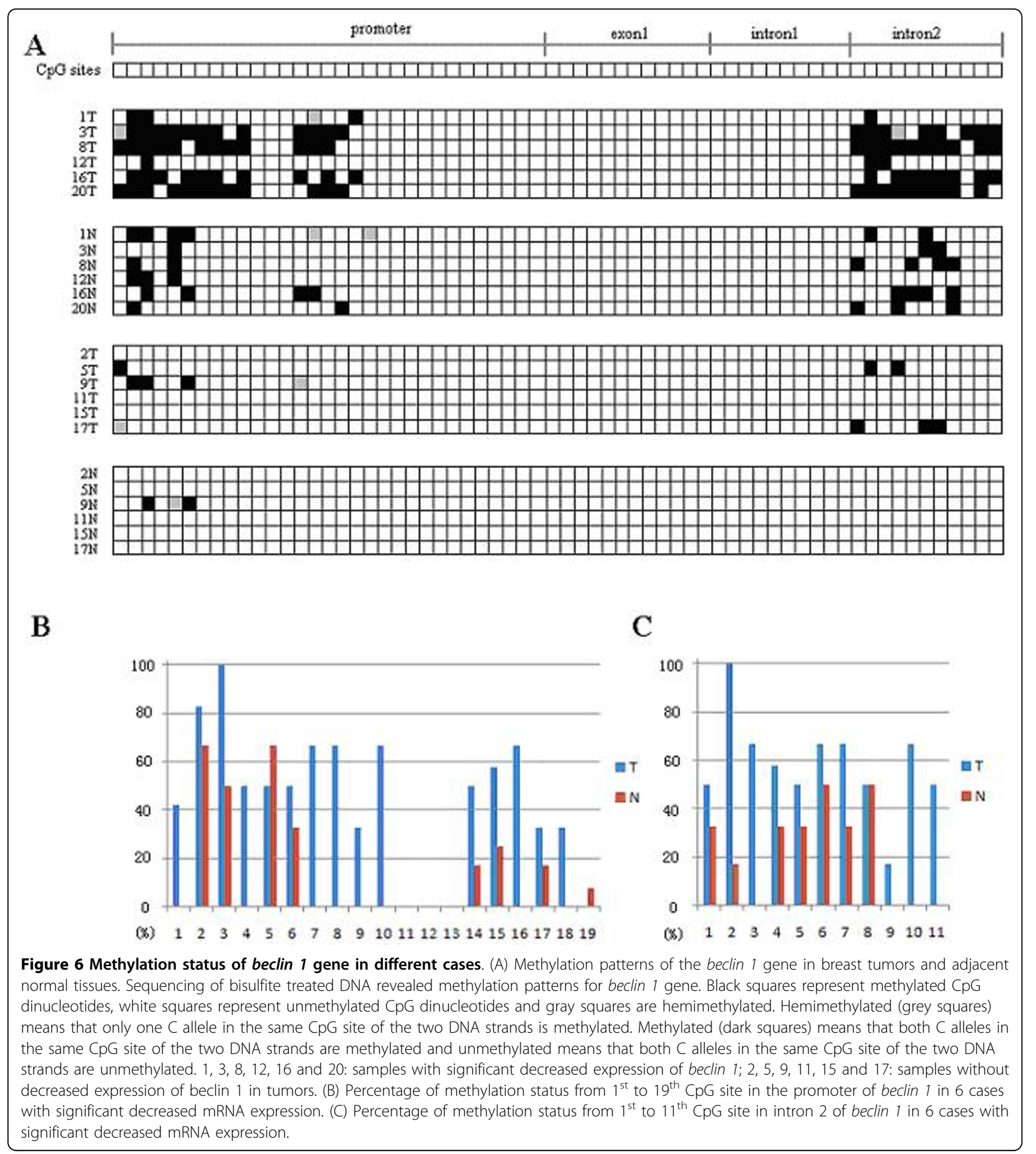

mutations were unlikely the main regulatory mechanism for beclin 1 inactivation in breast cancer. Meanwhile, allelic loss of beclin 1 was only found in a portion of the breast tumors with down-regulated expression, indicating that mechanisms other than allelic deletion may be responsible for the decrased mRNA expression.
The CpG island in beclin 1 spans over $1.5 \mathrm{~kb}$ from the promoter to the intron 2 [nucleotide (nt) -528 to 977] with the transcription start site defined as +1 , so it is divided into four regions to be cloned. The first region contained part of the beclin 1 promoter from -528 to -65 . The second region was located between -83 and 164 from the proximal promoter to part of the first 
intron. The third region laid between 137 and 400 from a portion of the first intron to part of the second exon. The fourth region was situated between 733 and 977 from a portion of the second intron. We found that certain CpG dinucleotides at the promoter and the intron 2 of the beclin 1 gene are hypermethylated in breast tumors. As dense methylation of the $5^{\prime} \mathrm{CpG}$ islands was not detected in normal tissues, we speculated that this methylation patterns in tumor cells were aberrant and disease associated. As a whole, the regulation of beclin 1 expression was a little complicated. In some cases, T16 and T20, the decreased expression was due to aberrant DNA methylation; While in T1 and T12, the decrease was from $\mathrm{LOH}$; And in the other cases, T3 and T8, both aberrant DNA methylation and LOH devoted to the decreased expression of beclin 1 (Table 8). For this reason, different mechanisms seemed to be involved in the regulation of beclin 1 expression.

Some tumors (T10 and T19) with low expression of beclin 1 did not have either $\mathrm{LOH}$ or methylation. Other identified mechanisms might contribute to the regulation of beclin 1 expression, such as bcl-2 overexpression [40]. Recently, a novel beclin 1 binding protein, UVRAG, was found to positively regulate autophagy signaling pathway mediated by beclin 1 in colon cancer [41]. Exploring different involving factors that could affect the regulatory expression of beclin 1 might contribute to the pathogenesis of human cancers.

Aberrant methylation of $5^{\prime} \mathrm{CpG}$ islands associated with down-regulated mRNA expression of beclin 1 indicated that methylation might be a new mechanism for loss of expression of beclin 1, which has not been shown previously. Sequence analysis revealed that there were four putative consensus Sp1 binding sites at the promoter [17] and one putative Sp1 binding site at the intron 2, which share high sequence homology to the consensus Sp1 motif. It has been reported that aberrant DNA hypermethylation in the promoter of a gene can silence its expression [42], and that methylation in the introns can silence or enhance its expression [43-45]. Whether DNA methylation in the promoter and the

Table 8 Summary of LOH and aberrant DNA methylation in breast tumors showing down - regulated expression of beclin 1

\begin{tabular}{ccc}
\hline No. & LOH & DNA Methylation \\
\hline 1 & + & - \\
3 & + & + \\
8 & + & + \\
12 & + & - \\
16 & - & + \\
20 & - & + \\
\hline
\end{tabular}

intron 2 of beclin 1 affects the binding affinity of transcriptional factor needs to be further determined.

\section{Conclusions}

In conclusion, our studies confirmed that down-regulation of beclin 1 expression is present in breast cancer. Other than deletion in gene copy number, DNA hypermethylation in the promoter and/or intron 2 may be a new mechanism responsible for down-regulation of beclin 1 expression. Since beclin 1 has important functions in apoptosis and autophagy, its epigenetic modification might provide new targets for cancer therapy.

\section{Acknowledgements}

This project is supported by Tsinghua-Yue-Yuen Medical Sciences Fund, Foundation for the Mainstay Talents of Tsinghua University, National Natural Science Foundation of China (NSFC) Grants 30670851, Wu Shunde Medical Science Research Fund and the Key Project of Chinese Ministry of Education (No. 03180), Foundation of Science and Technology Bureau of Liaoning Province of China (No. 20061038), Foundation of Educational Commission of Liaoning Province of China (No. 2008762).

\section{Author details}

'Institute of Biomedical Informatics, School of Medicine, Tsinghua University, Beijing, PR China. ${ }^{2}$ Department of Biological Science and Biotechnology, Tsinghua University, Beijing, PR China. ${ }^{3}$ Ministry of Education Key Laboratory of Bioinformatics, Tsinghua University, Beijing, PR China. ${ }^{4}$ Department of Surgical Oncology, The First Affiliated Hospital, China Medical University, Shenyang, PR China.

\section{Authors' contributions}

LZD carried out molecular biological studies, participated data collection, analysis and the preparation of the manuscript. CB and JF collected tissue samples and participated in the clinical part of the study and immunohistochemistry. WYQ, XYJ and LXJ supervised the project and overviewed the analysis of the data and the manuscript. All authors have read and approved the present manuscript.

\section{Competing interests}

The authors declare that they have no competing interests.

Received: 15 February 2009 Accepted: 16 March 2010 Published: 16 March 2010

\section{References}

1. Edinger AL, Thompson CB: Defective autophagy leads to cance. Cancer Cell 2003, 4:422-424.

2. Klionsky DJ, Emr SD: Autophagy as a regulated pathway of cellular degradation. Science 2000, 290:1717-1721.

3. Liang XH, Jaskon S, Seaman M, Brown K, Kempkes B, Hibshoosh H, Levine B: Induction of autophagy and inhibition of tumorigenesis by beclin 1 . Nature 1999, 402:672-676.

4. Yue Z, Jin S, Yang C, Yang C, Levine B: Beclin 1, an autophagy gene essential for early embryonic development, is a haploinsufficient tumor suppressor. Proc Natl Acad Sci 2003, 100:15077-15082.

5. Liang XH, Kleeman LK, Jiang HH, Gordon G, Goldman JE, Berry G, Herman B, Levine B: Protection against fatal Sindbis virus encephalitis by Beclin, a novel Bcl-2 interacting protein. J Virol 1998, 72:8586-8596.

6. Liang XH, Yu J, Brown K, Levine B: Beclin 1 contains a leucine-rich nuclear export signal that is required for its autophagy and tumor suppressor function. Cancer Res 2001, 61:3443-3449.

7. Furuya D, Tsuji N, Yagihashi A, Watanabe N: Beclin 1 augmented cisdiamminedichloroplatinum induced apoptosis via enhancing caspase-9 activity. Exp Cell Res 2005, 307:26-40. 
8. Daniel F, Legrand A, Pessayre D, Vadrot N, Descatoire V, Bernuau D: Partial Beclin 1 silencing aggravates doxorubicin- and Fas-induced apoptosis in HepG2 cells. World J Gastroenterol 2006, 12:2895-2900.

9. Aita VM, Liang XH, Murty W, Pincus DL, Yu WP, Cayanis E, Kalachikov S, Gilliam TC, Levine B: Cloning and genomic organization of beclin 1, a candidate tumor suppressor gene on chromosome 17q21. Genomics 1999, 59:59-65.

10. Russell SE, Hickey Gl, Lowry WS, White P, Atkinson RJ: Allele loss from chromosome 17 in ovarian cance. Oncogene 1990, 7:2069-2072.

11. Sato T, Saito H, Morita R, Koi S, Lee $H$, Nakamura Y: Allelotype of human ovarian cancer. Cancer Res 1991, 51:5118-5122.

12. Futreal PA, Soderkvist P, Marks JR, Iglehart JD, Cochran C, Barrett JC, Wiseman RW: Detection of frequent allelic loss on proximal chromosome $17 q$ in sporadic breast carcinoma using microsatellite length polymorphisms. Cancer Res 1992, 52:2624-2627.

13. Gao X, Zacharek A, Salkowski A, Grignon DJ, Sakr W, Porter AT, Honn KV: Loss of heterozygosity of the BRCA1 and other loci on chromosome $17 q$ in human prostate cancer. Cancer Res 1995, 55:1002-1005.

14. Miremadi A, Oestergaard MZ, Paul PD, Caldas C: Cancer genetics of epigenetic genes. Hum Mol Genet 2007, 16:28-49.

15. Widschwendter $M$, Jones PA: The potential prognostic, predictive, and therapeutic values of DNA methylation in cancer. Clin Cancer Res 2002, 8:17-21.

16. Esteller M, Corn PG, Baylin SB, Herman JG: A gene hypermethylation profile of human cancer. Cancer Res 2001, 61:3225-3229.

17. Weinmann AS, Bartley SM, Zhang T, Zhang MQ, Farnham PJ: Use of chromatin immunoprecipitation to clone novel E2F target promoters. Mol Cell Biol 2001, 21:6820-6832.

18. Livak KJ, Schmittgen TD: Analysis of relative gene expression data using real-time quantitative PCR and the $2^{-\Delta \Delta} C_{T}$ method. Methods 2001, 25:402-408.

19. Herman JG, Graff JR, Myohanen S, Nelkin BD, Baylin SB: Methylationspecific PCR: A novel PCR assay for methylation status of CPG islands. Proc Natl Acad Sci 1996, 93:9821-9826.

20. Roessler M, Rollinger W, Mantovani-Endl L, Roessler M, Rollinger W, Mantovani-Endl L, Hagmann ML, Palme S, Berndt P, Engel AM, Pfeffer M, Karl J, Bodenmüller H, Rüschoff J, Henkel T, Rohr G, Rossol S, Rösch W, Langen H, Zolg W, Tacke M: Identification of PSME3 as a Novel Serum Tumor Marker for Colorectal Cancer by Combining Two-dimensional Polyacrylamide Gel Electrophoresis with a Strictly Mass Spectrometrybased Approach for Data Analysis. Mol Cell Proteomics 2006, 5:2092-2101.

21. Zhang Q, Mashima Y, Noda S, Y Imamura, Kudoh J, Shimizu N, Nishiyama T, Umeda S, Oguchi Y, Tanaka Y, Iwata T: Characterization of AOC2 gene encoding a copper-binding amine oxidase expressed specifically in retina. Gene 2003, 318:45-53.

22. Wilson FH, Kahle KT, Sabath E, Lalioti MD, Rapson AK, Hoover RS, Hebert SC, Gamba G, Lifton RP: Molecular pathogenesis of inherited hypertension with hyperkalemia: The $\mathrm{Na}-\mathrm{Cl}$ cotransporter is inhibited by wild-type but not mutant WNK4. Proc Natl Acad Sci USA 2003, 100:680-684.

23. Feltus FA, Lee EK, Costello JF, Plass C, Vertino PM: Predicting aberrant CpG island methylation. Proc Natl Acad Sci 2003, 100:12253-12258.

24. Ushijima T: Detection and interpretation of altered methylation patterns in cancer cells. Nat Rev Cancer 2005, 5:223-231.

25. O'Connell P, Pekkel V, Fuqua SA, Osborne CK, Clark GM, Allred DC: Analysis of Loss of Heterozygosity in 399 Premalignant Breast Lesions at 15 Genetic Loci. J Natl Cancer Inst 1998, 90:697-703.

26. Dobrovic A, Simpfendorfer D: Methylation of the BRCA1 Gene in Sporadic Breast Cancer. Cancer Res 1997, 57:3347-3350.

27. Wei M, Grushko TA, Dignam J, Hagos F, Nanda R, Sveen L, Xu JH, Fackenthal J, Tretiakova M, Das S, Olopade Ol: BRCA1 promoter methylation in sporadic breast cancer is associated with reduced BRCA1 copy number and chromosome 17 aneusomy. Cancer Res 2005, 65:10692-10699.

28. Rice JC, Massey-Brown KS, Futscher BW: Aberrant methylation of the BRCA1 CpG island promoter is associated with decreased BRCA1 mRNA in sporadic breast cancer cells. Oncogene 1998, 17:1807-1812.

29. Mueller CR, Roskelley CD: Regulation of BRCA1 expression and its relationship to sporadic breast cancer. Breast Cancer Res 2002, 5:45-52.

30. Coles C, Condie A, Chetty U, Steel M, Evans HJ, Prosser J: P53 mutations in breast cancer. Cancer Res 1992, 52:5291-5298.
31. Greenblatt MS, Chappuis PO, Bond JP, Hamel N, Foulkes WD: TP53 mutations in breast cancer associated with BRCA1 or BRCA2 germ-line mutations: distinctive spectrum and structural distribution. Cancer Res 2001, 61:4092-4097.

32. Lakhani SR, Jacquemier J, Sloane JP, Gusterson BA, Anderson TJ, Vijver MJ, Farid LM, Venter D, Antoniou A, Storfer-Isser A, Smyth E, Steel CM, Haites N, Scott RJ, Goldgar D, Neuhausen S, Daly PA, Ormiston W, Mcmanus R, Scherneck S, Ponder BA, Ford D, Peto J, Stoppa-Lyonnet D, Easton DF: Multifactorial analysis of differences between sporadic breast cancers and cancers involving BRCA1 and BRCA2 mutations. J Natl Cancer Inst 1998, 90:1138-1145.

33. Lancaster JM, Wooster R, Mangion J, Phelan CM, Cochran C, Gumbs C, Seal S, Barfoot R, Collins N, Bignell G, Patel S, Hamoudi R, Larsson C, Wiseman RW, Berchuck A, Iglehart JD, Marks JR, Ashworth A, Stratton MR, Futreal A: BRCA2 mutations in primary breast and ovarian cancers. Nat Genet 1996, 13:238-240.

34. Thor AD, Moore DH, Edgerton SM, Kawasaki ES, Reihsaus E, Lynch HT, Marcus JN, Schwartz L, Chen LC, Mayall BH, Smith HS: Accumulation of p53 Tumor Suppressor Gene Protein: An independent marker of prognosis in breast cancers. J Natl Cancer Inst 1992, 84:845-855.

35. Hedenfalk I, Duggan D, Chen YC, Radmacher M, Bittner M, Simon R, Meltzer P, Gusterson B, Esteller M, Kallioniemi OP, Wilfond B, Borg A, Trent J: Gene-expression profiles in hereditary breast cancer. N Engl J Med 2001, 344:344-539.

36. Wilson CA, Ramos L, Villasenor MR, Anders KH, Press MF, Clarke K, Karlan B, Chen JJ, Scully R, Livingston D, Zuch RH, Kanter MH, Cohen S, Calzone FJ, Slamon DJ: Localization of human BRCA1 and its loss in high-grade, noninherited breast carcinomas. Nat Genet 1999, 21:236-240.

37. Welcsh PL, Owens KN, King MC: Insights into the functions of BRCA1 and BRCA2. Trends Genet 2000, 16:69-74

38. Gowen LC, Avrutskaya AV, Latour AM, Koller BH, Leadon SA: BRCA1 required for transcriptioncoupled repair of oxidative DNA damage. Science 1998, 281:1009-1012.

39. XL X, Wagner KU, Larson D, Weaver Z, Li C, Ried T, Hennighausen L, Wynshaw-Boris A, Deng CX: Conditional mutation of Brca1 in mammary epithelial cells results in blunted ductal morphogenesis and tumour formation. Nat Genet 1999, 22:37-43.

40. Pattingre S, Tassa A, Qu X, Garuti R, Liang XH, Mizushima N, Packer M, Schneider MD, Levine B: Bcl-2 antiapoptotic proteins inhibit Beclin 1dependent autophagy. Cell 2005, 122:927-39.

41. Liang C, Feng P, Ku B, Dotan I, Canaani D, Oh BH, Jung JU: Autophagic and tumor suppressor activity of a novel Beclin 1-binding protein UVRAG. Nat Cell Biol 2006, 8:688-698.

42. Herman JG, Baylin SB: Gene silencing in cancer in association with promoter hypermethylation. N Engl J Med 2003, 349:2042-2054.

43. Douglas DB, Akiyama Y, Carraway H, Belinsky SA, Esteller M, Gabrielson E, Weitzman S, Williams T, Herman JG, Baylin SB: Hypermethylation of a small CpGuanine-rich region correlates with loss of activator protein-2alpha expression during progression of breast cancer. Cancer Res 2004, 64:1611-1620.

44. Unoki M, Nakamura Y: Methylation at CpG islands in intron 1 of EGR2 confers enhancer-like activity. FEBS Lett 2003, 554:67-72.

45. Cheng CK, Chow WC, Loo TY, Chan TK, Chan V: The cell cycle checkpoint gene Rad9 is a novel Oncogene activated by $11 \mathrm{q} 13$ amplification and DNA methylation in breast cancer. Cancer Res 2005, 65:8646-8654.

\section{Pre-publication history}

The pre-publication history for this paper can be accessed here: http://www.biomedcentral.com/1471-2407/10/98/prepub

\section{doi:10.1186/1471-2407-10-98}

Cite this article as: $L i$ et al:: Genetic and epigenetic silencing of the beclin 1 gene in sporadic breast tumors. BMC Cancer 2010 10:98. 